\title{
A Szülói Bevonódás a Sportban Kérdőív hazai adaptációja
}

\author{
KOVÁCS KRISZTINA ${ }^{1 *}$ - F. FÖLDI RITA² - SMOHAI MÁTÉ2 - \\ GÉCZI GÁBOR ${ }^{1}$ - GYÖMBÉR NOÉMI ${ }^{1}$ \\ ${ }^{1}$ Testnevelési Egyetem, Gazdaság és Társadalomtudományi Intézet, \\ Pszichológia és Sportpszichológia Tanszék, Budapest \\ ${ }^{2}$ Károli Gáspár Református Egyetem, Pszichológiai Intézet, Budapest
}

(Beérkezett: 2019. szeptember 5.; elfogadva: 2020. március 18.)

\begin{abstract}
Háttér és célkitüzések: Jelen tanulmány célja a Szülői Bevonódás a Sportban Kérdőív magyar változatának (PISQ-H) pszichometriai vizsgálata, a mérőeszköz reliabilitásának és validitásának ellenőrzése. Módszer: A keresztmetszeti kutatás keretében a kérdőív érvényességét és megbízhatóságát 13-21 év közötti ( $M=16,76$ év; SD = 2,79 év) 471 fős (40,3\% fiú és 54,2\% lány, 5,5\% hiányzó adat) kényelmi mintán ellenőriztük. A fent említett kérdőivv mellett felvételre került az Észlelt Szülői Autonómiatámogatás Kérdőív is. Eredmények: A feltáró faktoranalízis során négy elkülönülő faktort kaptunk (Dicséret és támogatás, Szülői nyomásgyakorlás, Aktív bevonódás, valamint Direkt, kontrolláló viselkedés). A kérdőív alskáláinak belső megbízhatósága megfelelőnek bizonyult (Cronbach- $a$ : 0,64$0,85)$. A mérőeszköz időbeli stabilitásának vizsgálata során szignifikáns $(p<0,001)$, pozitív irányú, erős teszt-reteszt korrelációs együtthatókat kaptunk (Dicséret és támogatás alskála: $r(67)=0,82$; Szülői nyomásgyakorlás alskála: $r(67)=0,81$; Direkt, kontrolláló viselkedés alskála: $r(67)=0,93$; és Aktív bevonódás alskála: $r(67)=0,94$. A konstruktum validitás vizsgálata során a korábbi kutatásokkal megegyező, gyenge-mérsékelt erősségú korrelációt kaptunk a PISQ-H két alskálája és az Észlelt Szülői Autonómiatámogatás Kérdőív között $(r=0,30-0,56 ; p<0,001)$. Következtetések: A Szülői Bevonódás a Sportban Kérdőív kérdőív magyar változata pszichometriailag megfelelő mérőeszköznek tekinthetó.
\end{abstract}

Kulcsszavak: Szülői Bevonódás a Sportban Kérdőív, PISQ, sport, szülői bevonódás, utánpótlás

\footnotetext{
* Levelező szerzó: Kovács Krisztina, Testnevelési Egyetem, Pszichológiai és Sportpszichológiai Tanszék, 1123 Budapest, Alkotás u. 44. E-mail: kovacs.krisztina@tf.hu
} 


\section{Bevezetés}

\subsection{Szülői bevonódás a sportban}

A szülői bevonódás egy többdimenziós konstruktumként határozható meg, amely tartalmazza a gyermek aktivitásához kapcsolódó gondolatokat és érzéseket, és gyakran jelenik meg támogató (szülői támogatás) vagy elváró (szülői nyomás) viselkedés formájában (Leff \& Hoyle, 1995). Olyan szülői magatartásformák összessége, amelyek közvetlenül vagy közvetve hatnak a gyermekek fejlődésére és teljesítményére, és amelynek kognitív, viselkedéses és személyes aspektusai is lehetnek (Grolnick \& Slowiaczek, 1994).

A korai kutatások eredményei szerint a szülői bevonódás mértéke a sportban U-alakú kapcsolatban van a gyermek által megélt stresszel és fordított U-alakú kapcsolatot mutat a sportban megélt öröm szintjével (Power \& Woolger, 1994; Stein, Raedeke, \& Glenn, 1999), azaz egy közepes szintú részvétel tekinthetó ideálisnak a gyermek szempontjából. A későbbi kutatások ellentmondásos eredményeket hoztak az észlelt nyomás és a sportban megélt öröm mértéke vagy a sportolói eredményesség közti kapcsolatot tekintve (Rodis, 2013; Stroebel, 2006), bár a vizsgálatok sportágra specifikusak (úszás) voltak, a korosztályok tekintetében pedig igen széles korosztályi mintát vettek alapul, mint például a belépó évektől (6-12 év között) a fiatal felnőttkorig. Egy vizsgálat eredményei szerint a gyermekük sportágába nagymértékben bevonódó szülő képes megfelelő módon támogatni a gyermekét (Wolfenden \& Holt, 2005), míg egy másik felmérés során nem találtak kapcsolatot a bevonódás mértéke, valamint a gyermek-szülő kapcsolat minősége között (Holt, Tamminen, Black, Mandigo, \& Fox, 2009). Eredményes és kevésbé eredményes sportolók szüleinek hozzáállását, támogatását és bevonódását tekintve jelentős különbségeket találtak (Siekańska, 2012): az eredményes sportolók családjában a gyermek és maga a sport is fontos értékkel bír, a szülők aktív részesei gyermekük sportéletének.

A sportban megjelenő szülői támogatás (Dorsch, Smith, \& Dotterer, 2016) olyan viselkedésként vagy szóbeli megjegyzésként írható le, amely elősegíti a gyermek számára fontos sporthoz kapcsolódó teljesítményt (pl.: lehetóségek és eszközök biztosítása, elismerés, a teljesítményhez kapcsolódó visszajelzések, az edzéseken és a versenyeken való részvétel). A megfelelő szülői támogatás olyan pozitív kimenetelekkel járhat, mint a gyermek sportban megélt öröme, elkötelezettsége, autonómiája és reális önészlelése. A témához kapcsolódó további kutatások eredményei felhívják a figyelmet arra, hogy a legtöbb gyermek elégedett a szülei bevonódásának a mértékével (Rodis, 2013; Stroebel, 2006), továbbá megfelelő minőségú és mennyiségú pozitív visszajelzést és dicséretet kap tőlük (Ede, Kamphoff, Mackey, \& Armentrout, 2012; Giannitsopoulou, Kosmidou, \& Zisi, 2010). 
A szülői nyomás a sportban egy irányító, kontrolláló szülői viselkedésként határozható meg, amelynek célja a szülők számára fontos sportolói válaszok és kimenetelek ösztönzése (O’Rourke, Smith, Smoll, \& Cumming, 2011) és olyan kevésbé adaptív kimenetelekhez kapcsolódik, mint a gyermeknek az önmaga teljesítményével kapcsolatos elégedetlensége és a teljesítményszorongása. Hoover-Dempsey és Sandler (1997) szerepkonstrukció elmélete szerint azok a szülők vonódnak be jobban gyermekeik iskoláztatásába, akik azt gondolják, hogy ez része a szülői szerepnek. Ugyanez a hatás megjelenhet a sportolás kontextusában is.

A szülók által kifejtett nyomás mértékének alapján háromféle szülői szerepet határozhatunk meg (Hellstedt, 1987). A szülői bevonódás hiánya viszonylag alacsony szintú érzelmi, anyagi vagy funkcionális támogatással jellemezhető szülői viselkedés. Ritkábban jelennek meg versenyeken, anyagilag kevésbé támogatják gyermekük sportolását és ritkábban vesznek részt a sportegyesület önkéntes programjaiban. Kevés érdeklődést mutatnak az edzői kapcsolattartásokon a gyermekük szakmai fejlődése iránt. A szülői érdeklődés hiánya negatívan hathat a sportoló önbizalmára, és az edzővel való kapcsolatára egyaránt (Hellstedt, 1987).

A közepes szintú részvétel esetében a szülői jelenlét erős, de szabad teret hagynak gyermeküknek a sporttal kapcsolatos döntéseiket tekintve. Minden visszajelzés érdekli óket, ami a gyermekük fejlődéséről és célkitúzéseiről szól, de nem szólnak bele az edző feladatkörébe. A szülőket reális elvárások és nyitott kommunikációs csatorna jellemzi. A bevonódás ezen mértéke a leghatékonyabb a fiatal számára (Hellstedt, 1987). A közepes mértékú észlelt szülői bevonódás, akárcsak a magas szintú szülői támogatás a gyermek nemétól függetlenül kapcsolatba hozható a sportban megélt öröm mértékével és az önértékeléssel egyaránt (Leff \& Hoyle, 1995), valamint az adott sportág fontosabb szerepet is tölt be a család életében (Hoyle \& Leff, 1997).

A bevonódás túlzott mértékénél a szülő́k nehezen tudják elválasztani önmaguk motivációit a gyermekükétől. Rejtett vagy sokszor nem tudatos céljuk, hogy a gyermekük a sport által kiemelkedő sikert érjen el. A gyermek értékelését a verseny végeredményétől teszik függővé, erősen teljesítményorientáltak. Előfordul, hogy túlságosan beleszólnak az edző-sportoló kapcsolatba, emiatt gyakoriak a konfliktusok az edzóvel (Hellstedt, 1987). A túlzott bevonódás egyik veszélye, hogy azt sugallhatja a fiatal felé, hogy a szülei számára csak akkor lehet jó és értékes, ha a sportban ügyesen és eredményesen szerepel (Sack, Tenenbaum, \& Pargman, 2006). A vizsgálatok eredményei szerint ez korai kiégéshez (Udry, Gould, Bridges, \& Tuffey, 1997) és lemorzsolódásához is vezethet (Henriksen, Stambulova, \& Roessler, 2010). A túlzott bevonódás legnagyobb problémája a felcserélődő szerepek csapdája (reversed dependency phenomenon; Smoll, Cumming, \& Smith, 2011), 
amikor a szülő a saját be nem teljesített céljait és vágyait a gyermek karrierjén keresztül szeretné átélni, amit a fiatal gyakran túlzott nyomásként észlel. A túlzott szülói bevonódást Tofler, Knap és Lardon (2005) egy kontinuum mentén helyezte el. A Távnyomással Elért Eredmény (Achievement by proxy distortion) a sportkörnyezetben azt a fajta tudatos vagy nem tudatos viselkedést takarja, amikor a szülő a gyermeke karrierjén keresztül szeretné magára vonni a figyelmet. Egy olyan állapot, amikor a gyermek egy potenciálisan kizsákmányoló helyzetbe kerülhet, amely során a rendszerben részt vevő felnőtt(ek) a saját szükségletei(ke)t, ambíciói(ka)t elégíti(k) ki bizonyos célok vagy eredmények elérése által. Az öt fázis a következő kontinuum mentén halad: normális szintú támogatás (egészséges szülői viselkedés a fejlődési igények figyelembevételével), rizikós áldozatvállalás (a gyerek céljait nem lehet elkülöníteni a szülői elvárásoktól), tárgyiasulás („egydimenziós" sportolói identitás kialakulása, kiemelt fókusz az eredményeken), potenciális kihasználás vagy abúzus (a gyermek a szülő céljait szolgáló „tárgygyá" válik, a szülő függ a gyermek eredményeitôl, karrierkárosító rizikók elvállalása), valamint maga az abúzus (megjelenik a gyermeket károsító viselkedés, amelynek testi, lelki, vagy akár szexuális formái is lehetnek).

Fontos megkülönböztetni az észlelt szülői nyomást a szülők által megítélt nyomás mértékétól. Az esetek többségében a szülők által érzékelt szint alacsonyabb a gyermek által megélt mértéktól (Kanters \& Casper, 2008). Egy 8-15 év közötti labdarúgók körében történő felmérés során azt találták, hogy a fiatalok erősebbnek érezték a szülók felől érkező irányító viselkedés szintjét, mint ahogy maguk a szülők jellemezték saját viselkedésüket (Goodman \& James, 2017).

\subsection{A Szülői Bevonódás a Sportban Kérdőív (PISQ) bemutatása}

Az eredeti Szülői Bevonódás a Sportban Kérdőív (Parental Involvement in Sport Questionnaire; PISQ; Lee \& MacLean, 1997) húsz itemet tartalmaz és három alskálából áll. A Direkt, kontrolláló viselkedés alskála (DV: 10 kérdés) azt méri, hogy a szülők milyen mértékben próbálják meg irányítani a gyermekük sporthoz kapcsolódó viselkedését. Az Aktív bevonódás alskála (AB: 5 kérdés) az edzéseken és versenyeken mutatott szülői részvétel mértékét értékeli, a Dicséret és támogatás alskála (DT: 4 kérdés) pedig a szülői viselkedésben az empátia és megértés szintjét méri fel. A szerzők hozzátettek egy, a Szülői nyomásra (SZNY: 1) vonatkozó kérdést, amely arra vonatkozik, hogy a szüló milyen mértékben várja el gyermekétól a jó teljesítményt és/vagy győzelmet, és amely tétel Wuerth, Lee és Alferman (2004) ajánlása után során önálló alskálaként szerepelt tovább. 
A kérdőív alskáláinak belső megbízhatósága a különböző nyelvi adaptációkban megfelelőnek bizonyult (1. táblázat). Ugyanakkor az eredmények szerint egyes nyelvi adaptációk során megváltozott a kérdőív szerkezete. A kérdőív német verziójában például az Aktív bevonódás alskála kettó, a Direkt, kontrolálló viselkedés alskála hat, a Dicséret és támogatás alskála hét és a Szülooi nyomás alskála pedig négy itemből tevődött össze (Wuerth és mtsai, 2004). A francia változat esetében az egyes alskálákhoz tartozó tételek száma a következőképpen alakult: AB: 5 tétel, DV: 7 tétel, DT: 4 tétel, és SZNY: 4 tétel (Bois, 2009). A görög változat felépítése pedig a következő: AB: 5 tétel, DV: 5 tétel, DT: 6 tétel, és SZNY: 2 tétel (Lazopoulou, 2006, id.: Giannitsopoulou és mtsai, 2010).

1. táblázat. A PISQ kérdőív alskáláinak Cronbach-a értéke a különböző nyelvi adaptációk esetében

\begin{tabular}{|l|c|c|c|c|c|}
\hline \multicolumn{1}{|c|}{ Skálák } & $\begin{array}{c}\text { Eredeti } \\
\text { (Lee \& } \\
\text { MacLean, } \\
\text { 1997) }\end{array}$ & $\begin{array}{c}\text { Spanyol } \\
\text { (Torregosa } \\
\text { és mtsai, } \\
\text { 2005) }\end{array}$ & $\begin{array}{c}\text { Német } \\
\text { (Wuerth } \\
\text { és mtsai, } \\
\text { 2004) }\end{array}$ & $\begin{array}{c}\text { Görög } \\
\text { (Lazopoulou, } \\
\text { 2006) }\end{array}$ & $\begin{array}{c}\text { Francia } \\
\text { (Bois, } \\
\text { 2009) }\end{array}$ \\
\hline $\begin{array}{l}\text { Direkt, kontrolláló } \\
\text { viselkedés }\end{array}$ & 0,82 & 0,83 & 0,85 & 0,79 & 0,82 \\
\hline Dicséret és támogatás & 0,60 & 0,72 & 0,79 & 0,77 & 0,80 \\
\hline Aktív bevonódás & 0,66 & 0,60 & 0,58 & 0,63 & 0,58 \\
\hline Szülöi nyomás & & & 0,63 & 0,62 & 0,87 \\
\hline
\end{tabular}

Mind a német (Wuerth és mtsai, 2004), mind a svéd (Rodis, 2013) mintán pozitív irányú, gyenge-közepes erősségú (német mintán: $r=0,30$; svéd mintán: $r=0,49)$ kapcsolatot találtak a Direkt, kontrolláló viselkedés és a Szülői nyomás alskálák között.

\subsection{A szülői viselkedés hatása gyermekük sportéletére - a PISQ kérdőívvel kapcsolatos eredmények}

Az észlelt és vágyott szülői bevonódás mértéke közti eltérés - a nemzetközi mintákon végzett kutatások eredményei alapján - hatással lehet a fiatal sportolók múködésmódjára. Egy görög vizsgálatban (Giannitsopoulou és mtsai, 2010) sportágak között is eltérés mutatkozott: a görög ritmikus gimnasztikázók és a szertornászok magasabb mértékú (észlelt) szülői aktív bevonódásról számoltak be, mint amennyit igényeltek volna (vágyott szint), 
továbbá a ritmikus gimnasztikázók esetében az észlelt szülói direkt, kontrolláló viselkedés mértéke is nagyobbnak bizonyult a vágyott mértékhez képest. Svéd utánpótláskorú úszók csoportjában a fiatal sportolók elégedettek voltak a szüleik direkt, kontrolláló viselkedése és a tólük érkezó dicséret és támogatás mértékével, azonban az aktív bevonódás és a szülői nyomás tekintetében magasabb mértékú részvétel igényét fejezték ki (Rodis, 2013). 13-17 éves amerikai sportolók között (Marsh, Zavilla, Acuna, \& Poczwardowski, 2015) szignifikáns eltérést találtak a Direkt, kontrolláló viselkedés és a Dicséret és támogatás alskálák vágyott és észlelt mértéke között - a direkt, kontrolláló viselkedés esetén a sportolók nagyobb mértékú szülői részvételre vágynak; míg a dicséret és támogatás valamint a szülői nyomásgyakorlás mértéke magasabbnak bizonyult a kívántnál. Amerikai jégkorongjátékosok vizsgálata során a fiatalok elégedetlennek bizonyultak a szülői bevonódás mértékével - nagyobb mértékú bevonódást kívántak tőlük. Ugyanakkor a szerzők nem találtak kapcsolatot a szülői bevonódás mértéke és a sportban megélt örömérzet között (Ede és mtsai, 2012). Egy vizsgálatban (Averill \& Power, 1995) mind az anya, mind az apa felól érkező dicséret és támogatás mértékét kapcsolatba hozták a gyermek sportban megélt örömérzetével, és negatív irányú kapcsolatot találtak az apai direkt, kontrolláló viselkedés és a gyermek erőfeszítése között. Továbbá, a felmérés eredményei szerint, amikor a szülők jobban bevonódnak, nagyobb az esélye az edzőkkel való konfliktusoknak.

\subsubsection{Nemi különbségek}

Egy korai kutatásban (Leff \& Hoyle, 1995) a lányok nagyobb mértékű szülői támogatásról számoltak be, ellenben a fiúk nagyobb nyomást észleltek az apai oldalról. Egy másik, későbbi vizsgálatban már nem mutatkozott szignifikáns különbség a nemek között (Ridley, 2013), aminek hátterében a szerző szerint az áll, hogy az elmúlt évtizedben a nők és lányok sportban való részvétele ugrásszerúen megnőtt.

Úgy túnik továbbá, hogy a szülők viselkedése eltérő jellegzetességekkel bír. Wuerth és munkatársai (2004) eredményei szerint a fiatal sportolók az anyák irányából inkább támogató, míg az apák felól inkább direkt, kontrolláló viselkedést észleltek. Mindezt egy spanyol kutatás eredményei is megerősítették (Amado, Sánchez-Oliva, González-Ponce, Pulido-González, \& Sánchez-Miguel, 2015). 


\subsubsection{A sportban megjelenő értékek és kompetenciák}

A szülői bevonódás hatással van a gyermek sportban megélt jóllétére és az észlelt képességek szintjére (Lagacé-Séguin \& Case, 2010). Egy olasz vizsgálat során (Danioni, Barni, \& Rosnati, 2017) a dicséret és támogatás bizonyult legfontosabb előrejelzőnek arra vonatkozólag, hogy a serdülő milyen mértékben fogadja el a szülei sporthoz kapcsolódó értékrendszerét. Mindez kedvez a fiatal sportolók elköteleződésének és csökkenti a korai lemorzsolódás veszélyét (Torregrosa \& mtsai, 2007). Egy másik kutatásban negatív irányú kapcsolatot mutattak ki a dicséret és támogatás és a sportolói amotiváció között csapatsportot úző fiatalok mintájában (Sánchez-Miguel, Leo, Sánchez-Oliva, Amado, \& García-Calvo, 2013). A szülói nyomás mértéke pedig negatív irányú kapcsolatban áll a sporthoz kapcsolódó elégedettséggel (Amado \& mtsai, 2015), amely az intrinzik motiváció pozitív és az amotiváció negatív prediktora.

Egy amerikai úszók (O’Rourke \& Smith, 2011) körében történő felmérés eredményei összefüggésbe hozták a direkt, kontrolláló szülői viselkedést és a sportolói szorongást. Figyelembe véve a szülői motivációs klíma hatását egy szezonon belül, a szülői direkt, kontrolláló viselkedés nagy mértéke és az alacsony szintú elsajátítási motivációs klíma - azaz az elsajátítást, megértést, a korábbi teljesítmény túlszárnyalását és az elsajátítási cél követését ösztönző környezet (Fejes, 2018) - fokozza a sportolói szorongást, míg a magas mértékú szülői nyomás és a magas szintú elsajátítási klíma csökkenti azt. Francia teniszjátékosokat vizsgálva (Bois, Lalanne, \& Delforge, 2009) pozitív irányú kapcsolatot találtak a direkt, kontrolláló viselkedés és a szülói nyomás valamint a verseny előtti szorongás között, továbbá női játékosok esetében negatív irányú kapcsolat mutatható ki a dicséret és támogatás és a verseny előtti szorongás között. Ezzel szemben a teljesítményszorongás és a szülói bevonódás mértéke, illetve típusa között spanyol és svéd úszókból álló mintákon nem tártak fel szignifikáns összefüggést (Ponseti, Sese, \& Garcia-Mas, 2016; Rodis, 2013).

\subsubsection{Karrierátmenet és sportágak közötti eltérések}

Azon sportolók esetében, akik sikeres karrierátmenetről (korosztályváltás) számoltak be, a szülők aktív bevonódása és a szülói direkt, kontrolláló viselkedés nagyobb mértéket mutatott, mint azoknál, akiknél nem történt átmenet és maradtak saját korosztályi kategóriájukban (Wuerth és mtsai, 2004). A direkt, kontrolláló viselkedés különösen a sportolás kezdeti 
éveiben bizonyult jellemzőnek a fenti vizsgálatban. Egy görög kutatás (Giannitsopoulou és mtsai, 2010) eredményei alapján a specializáció éveiben járó sportolók a dicséret és támogatás nagyobb mértékét igényelték a szüleik felől.

\subsection{A vizsgálat célja}

A PISQ kérdőív a nemzetközi szakirodalom és a kutatási eredmények alapján a gyermekük sportolásába való szülői bevonódás mértékének megállapítására megfelelőnek bizonyuló mérőeszköz. A szülői bevonódás témaköre a sportpszichológia utánpótlással foglalkozó területének meghatározó elemeként folyamatosan újabb kutatásokat inspirál. Jelen tanulmány célja, hogy ismertessük a kérdőív sportolóknak szóló változatát és bemutassuk a mérőeszköz pszichometriai jellemzőit. A konstruktum validitás ellenőrzésének céljából az Észlelt Szülői Autonómiatámogatás Kérdőívet (PASSES-H; Kovács, Gyömbér, F. Földi, \& Lénárt, megjelenés alatt) kérdőívet vettük alapul, mivel a szülői bevonódás kapcsolatot mutat a gyermek autonómiájának támogatásával (Gagné, 2003; Holt és mtsai, 2009).

\section{Módszer}

\subsection{Eljárás}

A PISQ kérdőív fordítását angolról magyarra három független személy végezte, majd a három változat összevetéséből és megvitatásából készült tételsort egy angol szakfordító fordította vissza az eredeti nyelvre. A visszafordítás ellenőrzését és jóváhagyását egy sportszakpszichológus szakfordító végezte. A kérdőívek magyar nyelvre fordítását a kérdőív jogtulajdonosa (Association for Physical Education, Taylor \& Francis Ltd. ${ }^{\odot}$ engedélyével) jogilag engedélyezte akadémiai kutatók részére.

Az adatfelvétel a Testnevelési Egyetem hallgatóinak közremúködésével, különböző egyetemi kurzusok keretében, kényelmi mintavételi eljárással történt: a hallgatók a szemináriumi munka részeként, általuk közvetlen vagy közvetett módon elért sportegyesületek, szakképzett edzők segítségével jutottak el a vizsgálati személyekhez.

A felkeresett szövetségeket, egyesületeket és a résztvevő kiskorú sportolók szüleit, valamint magukat a sportolókat egyaránt tájékoztattuk a vizsgálat céljáról és a mérőeszközök tartalmáról. Utánpótlás korosztályok (1318 év) esetében a szülőktól is kértünk beleegyező nyilatkozatot. A vizsgálatban résztvevő sportolók számára biztosítottuk az anonimitást. A kérdőívet egy online felületen lehetett kitölteni, amely 15 percet vett igénybe. A vizs- 
gálatra 2019. április és június között került sor. A kutatást a Testnevelési Egyetem Kutatásetikai Bizottsága jóváhagyta. Az etikai engedély száma: TE-KEB/No4/2019.

\subsection{Vizsgálati személyek}

A vizsgálatban való részvétel feltétele volt, hogy a kitöltők egy egyesület keretein belül, igazolt versenyzőként, rendszeresen vegyenek részt versenyeken. A kérdőívet 471, 13 és 21 év közötti utánpótláskorú sportoló töltötte ki $(M=16,76$ év; $\mathrm{SD}=2,79$ év), akik átlagosan heti 9,78 $(\mathrm{SD}=6,06)$ órát töltenek el edzéssel, valamint átlagosan 7,04 (SD = 3,45) éve gyakorolják jelenlegi sportágukat. A minta fóbb adatait a 2. táblázatban mutatjuk be.

2. táblázat. A minta jellemzői

\begin{tabular}{|l|l|c|c|}
\hline \multicolumn{2}{|c|}{ Változók } & $n$ & $\%$ \\
\hline \multirow{5}{*}{ Nem } & Férfi & 190 & 40,3 \\
\cline { 2 - 4 } & Nó & 255 & 54,2 \\
\cline { 2 - 4 } & Hiányzó adat & 26 & 5,5 \\
\hline \multirow{5}{*}{ Sportág } & Egyéni & 184 & 39,1 \\
\cline { 2 - 4 } & Csapat & 287 & 60,9 \\
\hline \multirow{5}{*}{ Versenyzés szintje } & Nemzetközi & 71 & 15,1 \\
\cline { 2 - 4 } & Országos & 258 & 54,8 \\
\cline { 2 - 4 } & Helyi & 92 & 19,5 \\
\cline { 2 - 4 } & Nem versenyzik* & 12 & 2,5 \\
\cline { 2 - 4 } & Hiányzó adat & 38 & 8,1 \\
\hline
\end{tabular}

Megjegyzés: * A felmérés aktuális időpontjában nem versenyzik

\subsection{Mérőeszközök}

A szociodemográfiai és sportolással kapcsolatos adatok körében rögzítésre került a sportoló neme és életkora, továbbá az alapadatok között a sportággal és sportolással kapcsolatos háttér-információkat is jegyeztük (sportág megnevezése, edzés heti óraszáma, az adott sportágban eltöltött évek száma és a versenyzés szintje). 
A Szülői Bevonódás a Sportban Kérdőív (Parental Involvement in Sport Questionnaire; PISQ; Lee \& MacLean, 1997) célja, hogy felmérje a szülói viselkedés sajátosságait sportkörnyezetben. Az eredeti, 20 kérdést tartalmazó kérdőív négy alskálából állt: Direkt, kontrolláló viselkedés; Szülői nyomásgyakorlás; Aktív bevonódás; valamint Dicséret és támogatás (ld. 3. táblázat). Az eredeti kérdőív kialakítása az úszás sportágához köthető, így a mérôeszköz hazai adaptációja során a sportágra specifikus kifejezéseket általánosítottuk és az az úszás sportág terminusait az általános „sport” kifejezéssel helyettesítettük („A szüleid mérgesek rád, ha úgy gondolják, hogy nem megy úgy az úszás, ahogy szerintük kellene?” helyett „A szüleid mérgesek rád, ha úgy gondolják, hogy nem megy úgy a sportolás, ahogy szerintük kellene?"), követve a nemzetközi kutatások példáit (Danioni és mtsai, 2017; Giannitsopoulou és mtsai, 2010; Marsh és mtsai, 2015). A válaszokat egy ötfokú Likert-típusú skálán lehetett bejelölni ( 1 = soha; 5 = mindig). A kérdőív nem tartalmaz fordított irányú tételeket. A skálákon elért magasabb pontértékek az adott szülői viselkedés erősebb jelenlétét jelzik.

3. táblázat. A Szülői Bevonódás a Sportban Kérdőív magyar változatának itemei és azok eredeti skálabesorolása

\begin{tabular}{|l|l|}
\hline Alskála & \multicolumn{1}{|c|}{ Tétel } \\
\hline DV & $\begin{array}{l}\text { 1. Egy verseny után a szüleid megmondják, hogy szerintük miben kell még } \\
\text { fejlődnöd? }\end{array}$ \\
\hline DV & $\begin{array}{l}\text { 2. Egy verseny előtt/alatt a szüleid hangosan szurkolnak és kiabálnak } \\
\text { neked? }\end{array}$ \\
\hline DV & $\begin{array}{l}\text { 3. Edzés közben vagy az edzésre vonatkozóan megmondják vagy jelzik } \\
\text { neked a szüleid, hogy mit kellene csinálnod? }\end{array}$ \\
\hline DV & $\begin{array}{l}\text { 4. A szüleid mérgesek rád, ha úgy gondolják, hogy nem megy úgy } \\
\text { a sportolás, ahogy szerintük kellene? }\end{array}$ \\
\hline DV A szüleid elmondják neked, hogy szerintük hogyan fejleszthetnéd tovább \\
a technikádat?
\end{tabular}


3. táblázat folytatása

\begin{tabular}{|c|c|}
\hline Alskála & Tétel \\
\hline DV & 10. A szüleid erőltetik, hogy keményebben eddz? \\
\hline DV & 11. Egy verseny előtt a szüleid megmondják neked, hogyan versenyezz? \\
\hline DT & $\begin{array}{l}\text { 12. Egy verseny után megdicsérnek a szüleid azért, mert minden tőled } \\
\text { telhetőt megtettél? }\end{array}$ \\
\hline DT & $\begin{array}{l}\text { 13. Egy verseny után a szüleid megdicsérnek azért amilyen helyezést/ } \\
\text { eredményt elértél? }\end{array}$ \\
\hline DT & $\begin{array}{l}\text { 14. Kimutatják a szüleid, hogy megértik az sportágaddal kapcsolatos } \\
\text { érzéseidet? }\end{array}$ \\
\hline $\mathrm{AB}$ & $\begin{array}{l}\text { 15. A szüleid szoktak önkénteskedni a versenyeken, mint rendező, } \\
\text { segítő vagy bármi más? }\end{array}$ \\
\hline $\mathrm{AB}$ & 16. A szüleid aktív szerepet vállalnak az egyesületed múködésében? \\
\hline $\mathrm{AB}$ & 17. A szüleid meg szokták beszélni a fejlődésedet az edződdel? \\
\hline $\mathrm{AB}$ & $\begin{array}{l}\text { 18. A szüleid bíztatnak arra, hogy elmondd nekik bármilyen problémádat } \\
\text { és aggodalmadat? }\end{array}$ \\
\hline $\mathrm{AB}$ & $\begin{array}{l}\text { 19. A szüleid úgy tervezik az étkezések időpontjait, hogy el tudj menni } \\
\text { edzésre vagy versenyre? }\end{array}$ \\
\hline SZNY & 20. A szüleid nyomást gyakorolnak rád a sporttal kapcsolatban? \\
\hline
\end{tabular}

Megjegyzés: $\mathrm{AB}=$ Aktív Bevonódás; $\mathrm{DV}=$ Direkt, kontrolláló viselkedés; $\mathrm{DT}=$ Dicséret és támogatás; SZNY = Szülői Nyomásgyakorlás.

Az Észlelt Szülői Autonómiatámogatás Kérdőív (Perceived Autonomy Support Scale for Exercise Settings; PASSES; Hagger \& mtsai, 2007; magyar változat: Kovács és mtsai, megjelenés alatt) célja, hogy felmérje, milyen mértékú autonómiát támogató viselkedést észlel a válaszadó a szülei felől. A kérdőív 12 itemből áll, nem tartalmaz fordított tételt. A kérdésekre a kitöltők hétfokú Likert-típusú skálán adják meg a választ ( 1 = egyáltalán nem értek egyet; $4=$ semleges; 7 = teljesen egyetértek). A magasabb pontértékek az autonómia támogatásának magasabb szintjét jelzik. A kérdőív belső megbízhatósága a jelen mintában megfelelőnek bizonyult (Cronbach- $a$ : $0,94)$. 


\subsection{Statisztikai elemzések}

A minta jellemzéséhez és az átlag-, szórás eredmények bemutatásához leíró statisztikát használtunk. Mivel az egyes nyelvi adaptációk eltérő faktorstruktúrát eredményeztek, a Szülői Bevonódás a Sportban Kérdőív (PISQ) magyar változata faktorszerkezetének vizsgálatára feltáró faktoranalízist végeztünk (maximum likelihood módszerrel és Varimax rotációval). A belső konzisztencia ellenőrzésére Cronbach-a értéket számoltunk. Pearson-féle korrelációs elemzéssel teszteltük a kéthetes időintervallumban mért tesztreteszt reliabitást, valamint a konvergens validitás vizsgálatához PISQ-H alskálái és az észlelt szülői autonómiatámogatás mértékét vizsgáló PASSESS-H kérdőív közötti kapcsolatot. Az adatok statisztikai elemzését IBM SPSS Statistics for Windows, Version 22.0 programmal végeztük.

\section{Eredmények}

\subsection{Feltáró faktoranalízis}

A Szülői Bevonódás a Sportban Kérdőív szerkezete, faktorstruktúrája a nemzetközi mintákon eltérőnek bizonyult (Bois, 2009; Lazopoulou, 2006, id.: Giannitsopoulou és mtsai, 2010; Torregosa és mtsai, 2005; Wuerth és mtsai, 2004), ezért fontosnak tartottuk a feltáró (exploratív) faktoranalízis elvégzését a magyar mintán.

A feltáró faktoranalízist (maximum likelihood módszer Varimax rotációval) az eredeti 20 itemen végeztük. Először azt teszteltük, hogy találunk-e olyan modellt, amelyben minden tétel jól és kizárólagosan illeszkedik egyegy faktorhoz. Székelyi és Barna (2002) útmutatását követve egy itemet akkor tekintettünk egy, és csakis egy faktorhoz tartozónak, ha a faktorsúlya nagyobb, mint 0,25 , illetve legalább kétszer nagyobb, mint bármely más faktoron mutatott faktorsúlya. Mivel jelentős kereszttöltések mutatkoztak (ld. 4. táblázat), egyenként elhagytuk az elemzésból a fenti kritériumoknak nem megfelelő itemeket - sorban először mindig a legkisebb töltésú tételt vontuk ki. 
4. táblázat. A Szülői Bevonódás a Sportban Kérdőív első feltáró faktoranalízisének eredménye

\begin{tabular}{|l|c|c|c|c|c|}
\hline Itemek & Kommunalitások & 1. faktor & 2. faktor & 3. faktor & 4. faktor \\
\hline PISQ1 & 0,65 & 0,25 & 0,74 & 0,18 & 0,11 \\
\hline PISQ2 & 0,23 & 0,25 & 0,08 & 0,27 & 0,30 \\
\hline PISQ3 & 0,46 & 0,53 & 0,40 & 0,08 & 0,11 \\
\hline PISQ4 & 0,41 & 0,49 & 0,32 & $-0,26$ & 0,06 \\
\hline PISQ5 & 0,57 & 0,42 & 0,61 & 0,13 & 0,09 \\
\hline PISQ6 & 0,72 & 0,29 & 0,79 & 0,10 & 0,04 \\
\hline PISQ7 & 0,56 & 0,65 & 0,35 & 0,11 & 0,08 \\
\hline PISQ8 & 0,51 & 0,02 & $-0,04$ & 0,71 & 0,06 \\
\hline PISQ9 & 0,51 & 0,34 & 0,63 & 0,04 & 0,01 \\
\hline PISQ10 & 0,33 & 0,53 & 0,19 & $-0,04$ & 0,13 \\
\hline PISQ11 & 0,71 & 0,82 & 0,15 & $-0,04$ & 0,13 \\
\hline PISQ12 & 0,63 & 0,01 & 0,05 & 0,79 & 0,03 \\
\hline PISQ13 & 0,53 & $-0,08$ & 0,04 & 0,72 & 0,06 \\
\hline PISQ14 & 0,38 & $-0,03$ & 0,21 & 0,57 & 0,13 \\
\hline PISQ15 & 0,59 & 0,09 & 0,01 & 0,07 & 0,76 \\
\hline PISQ16 & 0,64 & 0,13 & 0,09 & 0,09 & 0,78 \\
\hline PISQ17 & 0,36 & 0,33 & 0,21 & 0,18 & 0,42 \\
\hline PISQ18 & 0,41 & $-0,07$ & 0,23 & 0,58 & 0,13 \\
\hline PISQ19 & 0,14 & 0,09 & 0,26 & 0,18 & 0,17 \\
\hline PISQ20 & 0,35 & 0,55 & 0,15 & $-0,11$ & 0,12 \\
\hline
\end{tabular}

Az eljárás során összesen hat tétel (2., 3., 4., 7., 17. és 19. item) került törlésre. A végső modellben a KMO értéke 0,82, a Bartlett-féle szfericitásteszt eredménye pedig $X^{2}(91)=2356,1 ; p<0,001$. A végső modell egy négy faktorból álló megoldást adott, a tételek (összesen 14 item) számottevő kereszttöltése nélkül, a teljes variancia 54,2\%-át magyarázva (5. táblázat). A kapott faktorok a végső modellben a tartalmuk tekintetében megfeleltek a Lee és MacLean (2004) által meghatározott alskáláknak (Dicséret és támogatás; 
Szülői nyomásgyakorlás; Direkt, kontrolláló viselkedés; Aktív bevonódás), amivel az eredményeinket a faktorsúlyok és a kereszttöltések alapján vetettük össze (Costello \& Osborne, 2005).

Eredményeink szerint a faktorokhoz más tételek is tartoztak, mint az eredeti kérdőívnél. Míg az eredeti PISQ kérdőívben az Aktív bevonódás alskála öt itemból állt, a jelen mintán végzett feltáró faktorelemzés után csak két item sorolódott be ehhez a faktorhoz. A három további eredeti itemból két tétel a végső modellbe nem került be a számottevő kereszttöltések miatt, valamint egy item a faktorsúlya alapján a Dicséret és támogatás faktorhoz sorolódott. Az eredeti Direkt, kontrolláló viselkedés faktor tíz kérdéséből eredményeink szerint csak négy item került ehhez a faktorhoz, statisztikai okokból négy itemet törölnünk kellett (négy item keresztbe töltött), kettő pedig átsorolódott a Szülői nyomásgyakorlás skálához, majd az így kapott négytételes faktorszerkezettel folytattuk az elemzésünket. Az eredeti Dicséret és támogatás faktor négy kérdésből állt, az itemek besorolása után azonban a jelen mintában öt kérdésre bővült, mert az eredetileg az Aktív bevonódás alskálához tartozó egyik item átkerült ehhez a faktorhoz. Az eredeti Szülői nyomásgyakorlás alskála mindössze egy itemból állt, azonban a faktorelemzésünk után egy három itemból álló struktúra mutatkozott meg: két, eredetileg a Direkt, kontrolláló viselkedéshez tartalmazó item ugyanis ide sorolódott át.

Összefoglalóan elmondható, hogy a 14 tételes végső változat (PISQ-H kérdőív) négy faktora az itemek jelentése alapján lényegében megfelel az eredeti 20 itemes kérdőív (Lee \& MacLean, 2004) négy faktorának, így az egyes faktorok segítségével jól értelmezhetők a szülői bevonódás és viselkedésformák jellegzetességei.

A faktorok közötti korrelációs kapcsolatot Pearson-féle korrelációs elemzéssel vizsgáltuk meg. Egy kivétellel szignifikáns, pozitív irányú összefüggéseket kaptunk, amelyek azonban a Szülői nyomásgyakorlás és a Direkt, kontrolláló viselkedés faktorok között mutatkozó mérsékelt erősségú kapcsolattól eltekintve gyengének bizonyultak (6. táblázat). 


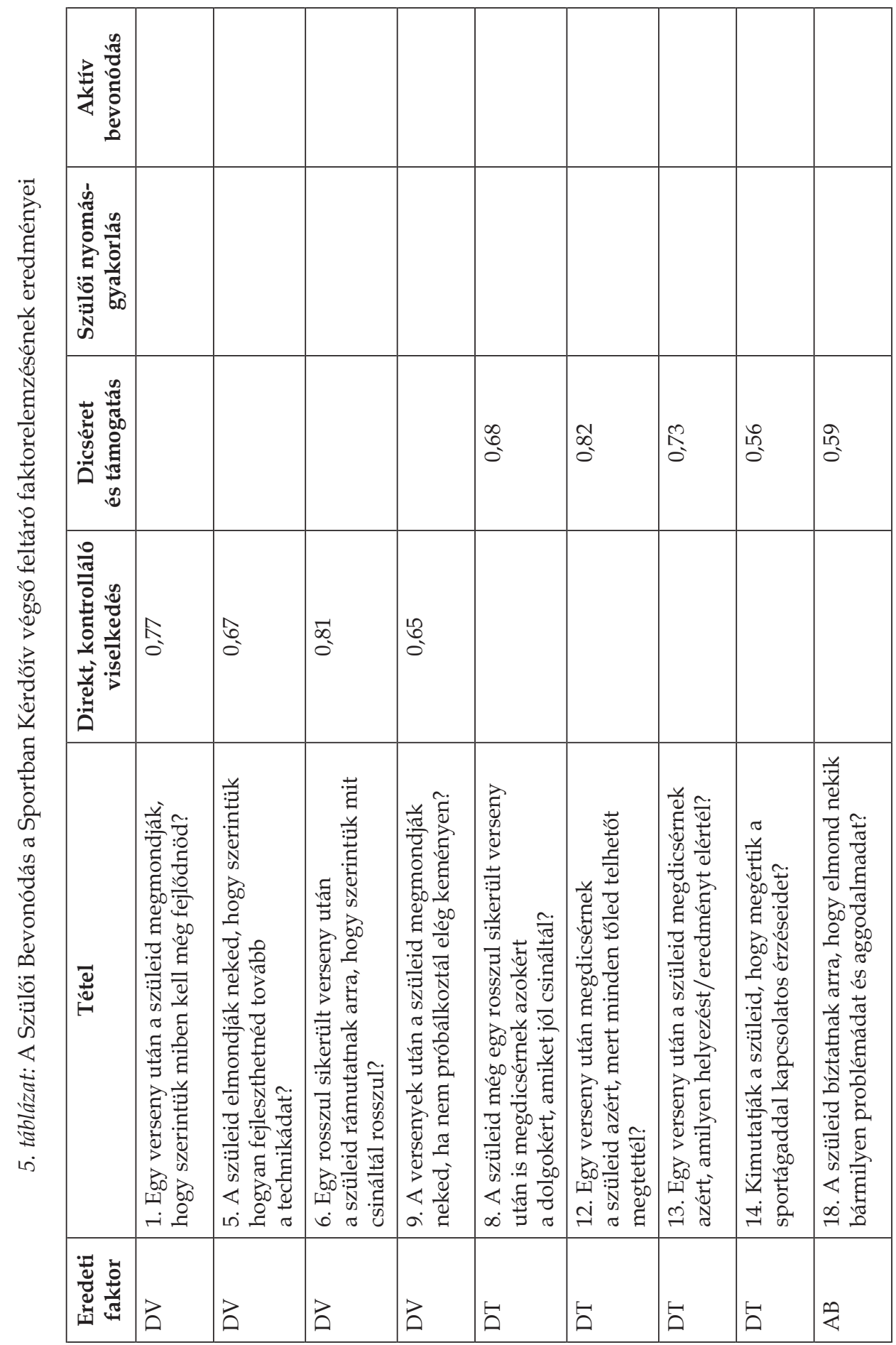



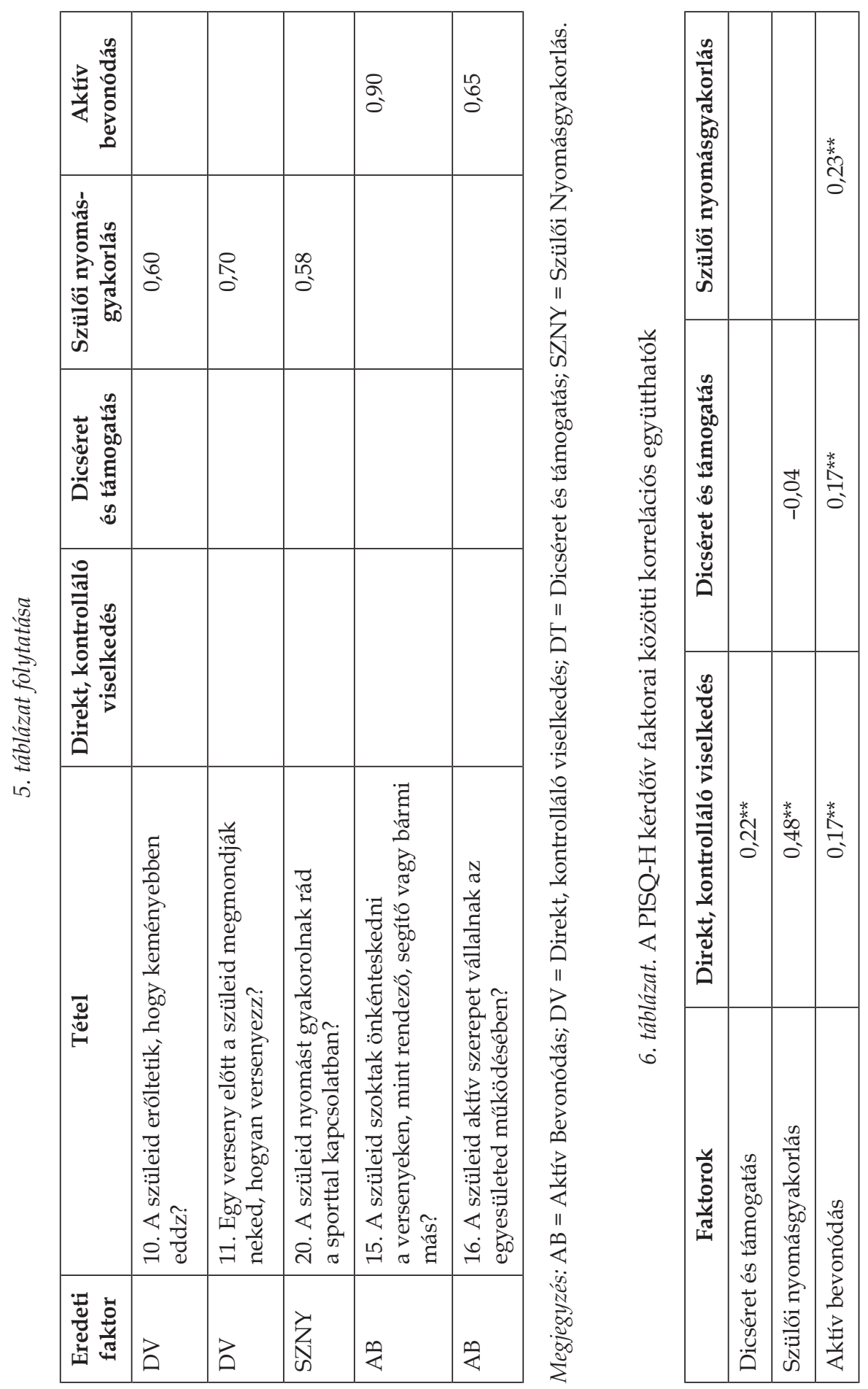

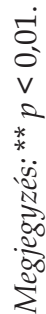




\subsection{Megbízhatóság}

\subsubsection{Belső konzisztencia}

A 14 tételesre redukált PISQ-H kérdőív alskálái megfelelő belső konzisztenciát mutatnak (Cronbach-a: 0,64-0,84) (7. táblázat). Az alskálák eloszlása a ferdeség és csúcsosság próbák eredményei alapján közel normális eloszlást mutat (lásd 7. táblázat), az adatok elemzésének céljából alkalmazott statisztikai próbák ennek figyelembevételével kerültek kiválasztásra.

7. táblázat. A PISQ-H kérdőív pszichometriai jellemzői

\begin{tabular}{|c|c|c|c|c|c|c|c|c|c|}
\hline \multirow{2}{*}{$\begin{array}{l}\text { A PISQ-H } \\
\text { kérdóív } \\
\text { alskálái }\end{array}$} & \multirow[t]{2}{*}{ Min. } & \multirow[t]{2}{*}{ Max. } & \multirow[t]{2}{*}{$\mathbf{M}$} & \multirow[t]{2}{*}{ SD } & \multicolumn{2}{|c|}{ Ferdeség } & \multicolumn{2}{|c|}{ Csúcsosság } & \multirow{2}{*}{$\begin{array}{l}\text { Cronbach- } a \\
\text { (tételszám) }\end{array}$} \\
\hline & & & & & Érték & SE & Érték & $\mathrm{SE}$ & \\
\hline $\begin{array}{l}\text { Dicséret } \\
\text { és támogatás }\end{array}$ & 6 & 25 & 21,11 & 4,00 & $-1,35$ & 0,11 & 1,44 & 0,22 & $\begin{array}{c}0,80 \\
(5)\end{array}$ \\
\hline $\begin{array}{l}\text { Direkt, } \\
\text { kontrolláló } \\
\text { viselkedés }\end{array}$ & 4 & 20 & 11,21 & 4,59 & 0,19 & 0,11 & $-0,97$ & 0,22 & $\begin{array}{c}0,85 \\
(4)\end{array}$ \\
\hline $\begin{array}{l}\text { Szülői } \\
\text { nyomás- } \\
\text { gyakorlás }\end{array}$ & 3 & 15 & 5,2 & 2,57 & 1,3 & 0,11 & 1,27 & 0,22 & $\begin{array}{l}0,64 \\
(3)\end{array}$ \\
\hline $\begin{array}{l}\text { Aktív } \\
\text { Bevonódás }\end{array}$ & 2 & 10 & 3,93 & 2,32 & 1,12 & 0,11 & 0,17 & 0,22 & $\begin{array}{c}0,76 \\
(2)\end{array}$ \\
\hline
\end{tabular}

Megjegyzés: $n=471$, Min. = minimum, Max. = maximum; $\mathrm{M}=$ átlag, SD = szórás; SE = standard hiba.

\subsubsection{Teszt-reteszt reliabilitás}

A kérdőíveket kéthetes eltéréssel töltötte ki a résztvevők egy kisebb csoportja. A 69 kitöltő közül 35 fiú és 24 lány (átlagéletkor: 16,61 év; SD = 1,67 év; terjedelem: 11-21 év). A Pearson-féle korrelációs elemzés eredményei szerint szignifikáns, pozitív irányú, erős kapcsolat található a két kitöltés között mind a négy alskála tekintetében. A korrelációs együttható értéke a Dicséret és támogatás alskála esetében $r(67)=0,823 ; p<0,001$; a Szülői nyomásgyakorlás alskálánál $r(67)=0,807 ; p<0,001$; a Direkt, kontrolláló viselkedés alskála kapcsán $r(67)=0,934 ; p<0,001$, az Aktív bevonódás alskála esetében pedig $r(67)=0,944 ; p<0,001$. 


\section{3. Érvényesség}

A konvergens validitás vizsgálatához PISQ-H alskálái és az észlelt szülői autonómia támogatás mértékét vizsgáló PASSESS-H közötti kapcsolatot Pearson-féle korrelációs vizsgálattal elemeztük. A PASSES-H szignifikáns, pozitív irányú kapcsolatot mutat a Dicséret és támogatás alskálával $(r(337)$ $=0,56 ; p<0,001)$, valamint a Direkt, kontrolláló viselkedés alskálával ( $r(337)$ $=0,30 ; p<0,001)$, a kapcsolat erőssége előbbi esetben közepes, utóbbival gyenge volt. Az észlelt szülói autonómiatámogatás és a Szülői nyomásgyakorlás mértéke között nem találtunk szignifikáns kapcsolatot $(r(337)=0,04$; $p=0,422)$, valamint szignifikáns, pozitív irányú, de elhanyagolhatóan gyenge kapcsolat mutatkozott az Aktív bevonódás alskálával $(r(337)=0,11$; $p=0,041)$.

\section{Megbeszélés}

A vizsgálat elsődleges célja a Szülői Bevonódás a Sportban Kérdőív (PISQ; Lee \& MacLean, 1997) hazai adaptációja és pszichometriai elemzése volt, sportolói mintán. A kérdőív a nemzetközi kutatási eredmények alapján megbízható mérőeszköznek bizonyult és az utánpótlássport területén kiemelt szerepet kapott a sportháromszög (sportoló - edzó - szüló) dinamikájának feltérképezésében (pl. Hellstedt, 1987; Tofler és mtsai, 2005).

A nemzetközi adaptációk során a kérdőív struktúrája megváltozott, az új verziók eltérő itemszámmal és faktorszámmal rendelkeznek (Bois, 2009; Lazopoulou, 2006, id.: Giannitsopoulou és mtsai, 2010; Torregrosa és mtsai, 2007; Wuerth és mtsai, 2004), ahogy a magyar verzió is eltér. Az eredeti, úszásra specifikus kérdőív átfogalmazásra került - a nemzetközi példáknak megfelelően. Az eredeti úszásra, illetve a különféle nyelvi adaptációk során alkalmazott sportra specifikus kifejezések általános, sportági specifikumoktól mentes kifejezésekre cserélődtek a magyar változat kidolgozása során.

A feltáró faktoranalízis eredményeképpen az eredeti 20 itemes kérdéssor 14 tételesre redukálódott (PISQ-H), megőrizve a négyfaktoros szerkezetet, amely azonban tartalmát tekintve némileg eltér az eredeti struktúrától (Lee \& MacLean, 2004). Az eredeti kérdőív Aktív bevonódás alskálája a magyar utánpótláskorú sportolói mintán csak két itemet tartalmaz, ami vélhetóen részben a kulturális különbségekre vezethető vissza. Az aktív szülői bevonódás kisebb mértékben jelenik meg a magyar egyesületek életében, és a szülők részvétele nem annyira transzparens a gyerekek számára, mint angolszász környezetben. Hazai viszonylatban nem, vagy csak kevés helyen elfogadott a szülói jelenlét az edzéseken, továbbá ritkán vállalnak a gyerek sportágával kapcsolatos önkéntes munkát. A legtöbb esetben az edzővel való kapcsolattartás mennyisége és minősége sem egyértelmú a gyermek 
számára, így a szülői aktív részvétel mértéke kívülről sokszor kevésbé észlelhető, szemben a kontrolláló, vagy a támogató viselkedés hatásaival. A Dicséret és támogatás alskála a magyar nyelvú változatban egy itemmel bővült, amely item tartalmában értelmezhetó aktív bevonódásként, ahova eredetileg is tartozott (érdeklődik gyermeke sportélete felől), de szülői támogatásként is (a gyermeket problémái megosztására ösztönözi), így az említett alskála tartalmába beilleszthetô. A Szülői nyomásgyakorlás alskála is további tételekkel bővült, amelyek eredetileg a Direkt, kontrolláló viselkedés alskálához tartoztak. Az egyik item az edzésmunkára vonatkozó aktív részvételre utal, ugyanakkor szóhasználatában a nyomásgyakorlás is tetten érhető („,erőltetik, hogy keményebben edz”), míg a másik a versenyzésre irányuló direkt szülői viselkedésre példa („,megmondják neked, hogyan versenyezz"), viszont szintén értelmezhető a szülői elvárásrendszer túlzott, nyomásgyakorlásra utaló megnyilvánulásaként.

A PISQ-H kérdőív belső megbízhatósága és időbeli konzisztenciája egyaránt megfelelőnek bizonyult a mintánkban. Az autonómia az öndeterminációs elmélet (Ryan és Deci, 2000) egyik központi fogalma. Az észlelt autonómiatámogatás az egyén azon meggyőződését tartalmazza, amely a számára fontos személyek (pl. tanárai, szülei, edzője vagy a barátai) olyan viselkedési mintáira vonatkozik, mint a kezdeményezókészség támogatása, a döntés lehetóségének biztosítása, a független problémamegoldás, a döntésekbe való bevonódás, valamint az érzések megosztása és elfogadása (Mageau \& Vallerand, 2003). A korábbi kutatások eredményei alátámasztották, hogy a megfelelő mértékú szülői bevonódás kapcsolatba hozható a nagyobb mértékú autonómiatámogató viselkedéssel (Gagné, 2003; Gronlick, Ryan, \& Deci, 1991). A szülői bevonódás egyik fontos jellemzője, hogy milyen mértékben jelenik meg az autonómiatámogató viselkedés a szülöi oldalon. Vizsgálatunk eredményei szerint az észlelt szülói autonómiatámogatás szignifikáns, pozitív irányú kapcsolatban áll a Dicséret és támogatás, a Szülői nyomásgyakorlás, valamint a Direkt, kontrolláló viselkedés alskálákkal, ami egyfelól egybecseng a korábbi kutatási eredményekkel (Amado és mtsai, 2015; Sanchez-Miguel és mtsai, 2013), másfelól pedig - a meglátásunk szerint - alátámasztja a PISQ-H kérdőív konstruktum validitását. Nem találtunk ugyanakkor szignifikáns együttjárást az Aktív bevonódás alskála és az észlelt szülői autonómiatámogatás mértéke között. Egy következő vizsgálatban érdemes lenne más kérdőívekkel is ellenőrizni a kérdőív konstruktum validitásának különféle aspektusait.

További kutatások során fontos lehet megvizsgálni az életkori sajátosságokat, valamint a sportágra specifikus jellegzetességeket. Eltéró szülói viselkedésmód jellemezheti azokat a szülőket, akinek gyermekei korai specializációjú sportágakat gyakorolnak (pl.: úszás, szertorna), hiszen az ilyen sportágak fokozottabb mértékú szülői részvételt igényelnek, mint például a 
csapatsportok. A gyermekek életkora is meghatározó: míg a sportolás kezdeti éveiben nagyobb mértékú szülői jelenlétre van szükség, addig a serdülőkor vége felé már szinte teljesen eltúnik a szülői szerepkör. Kezdetben a szülő és az edző egyaránt fontos szerepet játszik abban, hogy a sport és az edzések hatékonyan integrálódjanak a gyermek mindennapjaiba, viszont ahogy az edzések beépülnek a napi rutinba, egyre komolyabbá válnak és megjelenik az eredménykényszer, az egyesületek és az edzők igyekeznek a szülői feladatkör jelentőségét csökkenteni. A fiatal sportoló szempontjából az ideális szülői bevonódás mértéke és minőségének meghatározása egy kifejezetten megosztó kérdéskör. Több vizsgálat eredménye is kiemeli a túlzott mértékú bevonódás káros aspektusait (Power \& Woolger, 1994; Tofler és mtsai, 2005), ugyanakkor néhány kutatásban ezt a negatív hatást nem tudták kimutatni (Rodis, 2013; Stroebel, 2006), vagy éppen az ellenkezójére derült fény (Wolfenden \& Holt, 2005). A szülők számára is kényes terület a saját bevonódásuk mértékének megítélése és annak feltérképezése, milyen hatással bír gyermekük sportéletére. Szülőkkel készült interjúk tükrözik az arra vonatkozó kételyeket, hogy mikor érdemes hátrébb lépni a gyermek sportéletéből. Sok szülő megteszi ezt a lépést a gyermek idősebb életkorában, mégis később megbánják ezt a döntést (Clarke \& Harwood, 2014; Kerr \& Stirling 2012). A témakör megosztottsága és specifikumai miatt fontos lenne feltérképezni, hogy mi jellemző a magyar sportkörnyezetre, akár a sportolói oldalról nézve, akár a szülőket megkérdezve. Mindez fontos eredményekkel szolgálna a gyakorlati oldalon dolgozó szakemberek (pl. sportpszichológusok, szakedzók, sportorvosok és rehabilitációs szakemberek) számára is.

A kutatás egyik korlátja a kényelmi mintavételból fakad: a minta nem tekinthető reprezentatívnak ezért az eredményeink általánosíthatósága korlátozott. A vizsgálat nem tér ki a sportolói korosztályok sajátosságaira, azaz hogyan és miként változik a szülői bevonódás a gyermek életkorának tükrében, valamint további hiányossága, hogy nem jellemzi a különböző sportágak eltéréseit az adott tényezők viszonylatában. Következő vizsgálatok során fontos lenne kitérni mindezekre a sajátosságokra, valamint feltárni a korai specializációjú sportágak jellegzetességeit mindazokkal a sportágakkal szemben, ahol a korai elkötelezódés nem szükséges feltétel. A korosztályi csoportosítás okozta nehézségek és az eltérő sportolói fejlődéshez kapcsolódó sportpszichológiai modellek ismertetése olyan kihívások elé állítja a kutatókat, amely egy külön vizsgálat tárgyát képezné. Bár a fejlődési modellek filozófiájában számos hasonlóság fedezhetó fel, a kulcsfogalmai, illetve szempontjai eltérnek egymástól. A modellek kiemelik, hogy a fejlődési szakaszok kezdete sportáganként eltérő lehet, továbbá fontos megemlíteni azt is, hogy nemzetenként más-más elmélet/modell terjedt el (pl. Long Therm Athlete Development - Balyi, Higgs \& Way 2013; Holistic Athletic Career Modell 
- Wylleman \& Lavalee, 2004; Developmental Model of Sport Participation Côté \& Hay, 2002). A konstruktum validitás ellenőrzése során a Szülői nyomásgyakorlás alskála nem mutatott kapcsolatot az általunk vizsgált szülői autonómiatámogatás mértékével, így fontos lenne mindezt megismételni más, a szülői nyomásgyakorlással kapcsolatba hozható változóval, mint például az öndeterminált motiváció (Amado \& mtsai, 2015), vagy a sportolói szorongás mértéke (O’Rourke, Smith, Smoll, \& Cumming, 2011).

Összességében a Szülői Bevonódás a Sportban Kérdőív magyar változata (PISQ-H) jól alkalmazhatónak bizonyult a sportolók mintáján és megfelelő megbízhatósággal rendelkezik mind a belső konzisztencia, mind az idói stabilitás kapcsán. A kérdőív használatának bevezetése tovább gazdagíthatja az alkalmazott sportpszichológia gyakorlati szegmensét, segíti az utánpótlássport területén dolgozó szakemberek munkáját, és hozzájárul többek között az utánpótláskorú versenyzők pszichoszociális fejlődésének és a versenyzővé válás folyamatának hatékonyabb megismeréséhez.

\section{Irodalom}

Amado, D., Sánchez-Oliva, D., González-Ponce, I., Pulido-González, J.J., \& Sánchez-Miguel, P.A. (2015). Incidence of parental support and pressure on their children's motivational processes towards sport practice regarding gender. Plos One, 10(6). Doi:10.1371/journal. pone. 0128015

Averill, P., \& Power, T. (1995). Parental attitudes and children's experiences in soccer: Correlates of effort and enjoyment. International Journal of Behavioral Development, 18(2), 263-276.

Balyi, I., Way, R., \& Higgs, C. (2013). Long-term athlete development. Champaign, IL: Human Kinetics

Bois, J.E., Lalanne, J., \& Delforge, C. (2009). The influence of parenting practices and parental presence on childrens and adolescents pre-competitive anxiety. Journal of Sports Sciences, 27(10), 995-1005.

Clarke, N.J., \& Harwood, C.G. (2014). Parenting experiences in elite youth football: A phenomenological study. Psychology of Sport and Exercise, 15(5), 528-537.

Costello, A.B., Osborne, J.W. (2005). Best practices in exploratory factor analysis: Four recommendations for getting the most from your analysis. Practical Assessment, Research and Evaluation, 10(7), 1-9.

Côté, J. \& Hay, J. (2002). Family influences on youth sport participation and performance. In J.M. Silva, \& D. Stevens (Eds.), Psychological foundations of sport (503-519). Boston: Allyn and Bacon

Danioni, F., Barni, D., \& Rosnati, R. (2017). Transmitting sport values: The importance of parental involvement in children's sport activity. Europe's Journal of Psychology, 13(1), 75-92.

Dorsch, T.E., Smith, A.L., \& Dotterer, A.M. (2016). Individual, relationship, and context factors associated with parent support and pressure in organized youth sport. Psychology of Sport and Exercise, 23, 132-141. 
Ede, S., Kamphoff, C.S., Mackey, T., \& Armentrout, S.M. (2012). Youth hockey athletes' perceptions of parental involvement: They want more. Journal of Sport Behavior, 35(1), 3-18.

Fejes, B.J. (2018). Az osztálytársak szerepe a motivációs klíma észlelésében. Iskolakultúra, 28(10-11), 39-54.

Gagné, M. (2003). Autonomy support and need satisfaction in the motivation and well-being of gymnasts. Journal of Applied Sport Psychology, 15(4), 372-390.

Giannitsopoulou, E., Kosmidou, E., \& Zisi, V. (2010). Examination of parental involvement in Greek female athletes. Journal of Human Sport and Exercise, 5(2), 176-187.

Goodman M., \& James I.A. (2017). Parental involvement in young footballers' development: A comparison of the opinions of children and their parents. Sport and Exercise Psychology Review, 13(1), 2-9.

Grolnick, W.S., Ryan, R.M., \& Deci, E.L. (1991). Inner resources for school achievement: Motivational mediators of children's perceptions of their parents. Journal of Educational Psychology, 83(4), 508-517.

Grolnick, W.S., \& Slowiaczek, M.L. (1994). Parents' involvement in children's schooling: A multidimensional conceptualization and motivational model. Child Development, 65(1), 237-252.

Hagger, M.S., Chatzisarantis, N.L., Hein, V., Pihu, M., Soós, I., \& Karsai, I. (2007). The perceived autonomy support scale for exercise settings (PASSES): Development, validity, and cross-cultural invariance in young people. Psychology of Sport and Exercise, 8(5), 632-653.

Hellstedt, J. (1987). The coach/parent/athlete relationship. The Sport Psychologist, 1(2), 151-160.

Henriksen, K., Stambulova, N., \& Roessler, K.K. (2010). Holistic approach to athletic talent development environments: A successful sailing milieu. Psychology of Sport and Exercise, 11(3), 212-222.

Holt, N., Tamminen, K., Black, D., Mandigo, J., \& Fox, K. (2009). Youth sport parenting styles and practices. Journal of Sport and Exercise Psychology, 31(1), 37-59.

Hoover-Dempsey, K.V., \& Sandler, H.M. (1997). Why do parents become involved in their children's education? Review of Educational Research, 67(1), 3-42.

Hoyle, R.H., \& Leff, S.S. (1997). The role of parental involvement in youth sport participation and performance. Adolescence, 32(125), 233-244.

Kanters M.A., Bocarro J., \& Casper J.M. (2008). Supported or pressured? An examination of agreement among parents and children on parent's role in youth sports. The Journal of Sport Behavior, 31(1), 1-17.

Kerr, G.A., \& Stirling, A.E. (2012). Parents' reflections on their child's experiences of emotionally abusive coaching practices. Journal of Applied Sport Psychology, 24(2), 191-206.

Kovács, K., Gyömbér, N., F. Földi, R. \& Lénárt, Á. (in press). Észlelt Autonómia támogatás Kérdőívek hazai adaptációja. Alkalmazott Pszichológia.

Lagacé-Séguin, D.G., \& Case, E. (2010). Extracurricular activity and parental involvement predict positive outcomes in elementary school children. Early Child Development and Care, 180(4), 453-462.

Lazopoulou V. (2006). Exploration of perceived parental involvement in sports by athletes and parents. Unpublished dissertation. Trikala: University of Thessaly

Lee, M, \& Maclean, S. (1997). Sources of parental pressure among age group swimmers. European Journal of Physical Education, 2(2), 167-177.

Leff, S., \& Hoyle, R. (1995). Young athletes' perceptions of parental support and pressure. Journal of Youth and Adolescence, 24(2), 187-203. 
Marsh, A., Zavilla, S., Acuna, K., \& Poczwardowski, A. (2015). Perception of purpose and parental involvement in competitive youth sport. Health Psychology Report, 1, 13-23.

Mageau, G.A., \& Vallerand, R.J. (2003). The coach-athlete relationship: A motivational model. Journal of Sports Sciences, 21(11), 883-904.

O'Rourke, D.J., Smith, R.E., Smoll, F.L., \& Cumming, S.P. (2011). Trait anxiety in young athletes as a function of parental pressure and motivational climate: Is parental pressure always harmful? Journal of Applied Sport Psychology, 23(4), 398-412.

Ponseti, F.J., Sese, A., Garcia-Mas, A. (2016). The impact of competitive anxiety and parental influence on the performance of young swimmers, Revista Iberoamericana De Psicología Del Ejercicio Y El Deporte, 11(2), 229-237.

Power, T.G., \& Woolger, C. (1994). Parenting practices and age-group swimming: A correlational study. Research Quarterly for Exercise and Sport, 65(1), 59-66.

Ridley, M.J. (2013). Parental perceptions of their sport involvement with late adolescent student athletes. Unpublished doctoral dissertation, Ball State University. Letöltve: 2018. január 11-én: http:/ / cardinalscholar.bsu.edu/handle/123456789/197517

Rodis, A.G. (2013). Swedish swimmers' perception of parental involvement. Letöltve: 2018. január 11-én: http:/ /idrottsforum.org/rodis131126/

Ryan, R.M., Deci, E.L. (2002). Overview of self-determination theory: An organismic dialectical perspective. In E.L Deci \& R.M. Ryan (Eds.), Handbook of self-determination research (3-33). New York: The University of Rochester Press

Sacks, D.N., Tenenbaum, G., \& Pargman, D. (2006): Providing sport psychology services to families. In. J. Dosil (Ed.), The sport psychologist's handbook: A guide for sport-specific performance enhancement (39-61). New York: Wiley \& Sons

Sánchez-Miguel, P.A., Leo, F.M., Sánchez-Oliva, D., Amado, D., \& García-Calvo, T. (2013). The importance of parents' behavior in their children's enjoyment and amotivation in sports. Journal of Human Kinetics, 36(1), 169-177.

Siekańska, M. (2013). Athletes' perception of parental support and its influence in sports accomplishments - A retrospective study. Human Movement, 13(4), 380-387.

Smoll, F.L., Cumming, S.P., \& Smith, R.E. (2011). Enhancing coach-parent relationships in youth sports: Increasing harmony and minimizing hassle. International Journal of Sports Science and Coaching, 6(1), 3-26.

Stein, G.L., Raedeke, T.D., \& Glenn, S.D. (1999). Children's perceptions of parent involvement: it's not how much, but to what degree that's important. Journal of Sport Behavior, 22(4), 591-601.

Stroebel, L.C. (2006). Parental involvement in sport: perceptions of competitive adolescent swimmers (Unpublished doctoral dissertation, University of the Free State). Letöltve: 2018 január 11-én: https://scholar.ufs.ac.za/handle/11660/1708

Székelyi, M., \& Barna, I. (2002). Túlélőkészlet az SPSS-hez. Többváltozós elemzési technikákról társadalomkutatók számára. Budapest: Typotex Kiadó

Tofler, I.R., Knapp, P.K., \& Lardon, M.T. (2005). Achievement by proxy distortion in sports: A distorted mentoring of high-achieving youth. Historical perspectives and clinical intervention with children, adolescents, and their families. Clinics in Sports Medicine, 24(4), 805-828.

Torregrosa, M., Cruz, J., Sousa, C., Viladrich, C., Villamarín, F., Garcia-Mas, A., et al. (2007). La influencia de padres y madres en el compromiso deportivo de futbolistas jóvenes. Revista Latinoamericana de Psicología, 39(2), 227-237.

Udry, E., Gould, D., Bridges, D., \& Tuffey, S. (1997). People Helping People? Examining the Social Ties of Athletes Coping with Burnout and Injury Stress. Journal of Sport and Exercise Psychology, 19(4), 368-395. 
Wolfenden, L.E., \& Holt, N.L. (2005). Talent development in elite junior tennis: Perceptions of players, parents, and coaches. Journal of Applied Sport Psychology, 17(2), 108-126.

Wuerth, S., Lee, M.J., \& Alfermann, D. (2004). Parental involvement and athletes' career in youth sport, Psychology of Sport and Exercise, 5(1), 21-33.

Wylleman, P., \& Lavallee, D. (2004). A developmental perspective on transitions faced by athletes. In M.R. Weiss (Ed.), Developmental sport and exercise psychology: A lifespan perspective (507-527). Morgantown: Fitness Information Technology

\section{Köszönetnyilvánítás}

Kovács Krisztina az Innovációs és Technológiai Minisztérium ÚNKP-19-3-1 kódszámú Új Nemzeti Kiválósági Programjának szakmai támogatásával készült. A szerzők köszönetüket fejezi ki Takács Johannának az adatbázis-kezelésben nyújtott segítségéért.

\section{Szerzői munkamegosztás}

A kutatás szakmai és operatív vezetőjeként az elméleti háttér, az adatok statisztikai elemzése, és a kézirat szövegezése Kovács Krisztina munkája. Az elméleti háttér kidolgozásában és a méróeszköz fordításában való segédkezés, valamint az adatok értelmezése és a kézirat végső szövegezése Gyömbér Noémi munkájához tartozik. Az adatgyújtésben és a végső szöveg kialakításában Smohai Máté, míg a hipotézisek megfogalmazásában és a végső szöveg ellenőrzésében F. Földi Rita és Géczi Gábor vettek részt.

\section{Nyilatkozat érdekütközésról}

A szerzők ezúton kijelentik, hogy esetükben nem állnak fenn érdekütközések.

\section{FÜGGELÉK}

\section{Szülői Bevonódás a Sportban Kérdőív}

Az alábbiakban olyan kérdésekkel találkozhatsz, amelyekben sportolók személyes tapasztalataikat fejezik ki a szüleik sportban való részvételével kapcsolatban. Kérjük, hogy gondosan olvasd el az alábbi állításokat, majd jelöld be azt a válaszlehetőséget, amit magadra nézve a leginkább jellemzőnek tartasz:

$$
1=\text { soha } \quad 2 \text { = ritkán } \quad 3=\text { néha } \quad 4=\text { gyakran } \quad 5=\text { mindig }
$$

Kérjük, válaszolj úgy, hogy a válaszok a legpontosabban jellemző képet tükrözzék rólad. Befejezés előtt kérjük, még egyszer ellenőrizd, hogy egyetlen tétel se maradjon megválaszolatlanul! 


\begin{tabular}{|c|c|c|c|c|c|}
\hline $\begin{array}{l}\text { 1. Egy verseny után a szüleid megmondják, hogy szerintük } \\
\text { miben kell még fejlődnöd? }\end{array}$ & 1 & 2 & 3 & 4 & 5 \\
\hline $\begin{array}{l}\text { 2. A szüleid elmondják neked, hogy szerintük hogyan } \\
\text { fejleszthetnéd tovább a technikádat? }\end{array}$ & 1 & 2 & 3 & 4 & 5 \\
\hline $\begin{array}{l}\text { 3. Egy rosszul sikerült verseny után a szüleid rámutatnak } \\
\text { arra, hogy szerintük mit csináltál rosszul? }\end{array}$ & 1 & 2 & 3 & 4 & 5 \\
\hline $\begin{array}{l}\text { 4. A szüleid még egy rosszul sikerült verseny után is } \\
\text { megdicsérnek azokért a dolgokért, amiket jól csináltál? }\end{array}$ & 1 & 2 & 3 & 4 & 5 \\
\hline $\begin{array}{l}\text { 5. A versenyek után a szüleid megmondják neked, } \\
\text { ha nem próbálkoztál elég keményen? }\end{array}$ & 1 & 2 & 3 & 4 & 5 \\
\hline 6. A szüleid erőltetik, hogy keményebben eddz? & 1 & 2 & 3 & 4 & 5 \\
\hline $\begin{array}{l}\text { 7. Egy verseny előtt a szüleid megmondják neked, } \\
\text { hogyan versenyezz? }\end{array}$ & 1 & 2 & 3 & 4 & 5 \\
\hline $\begin{array}{l}\text { 8. Egy verseny után megdicsérnek a szüleid azért, } \\
\text { mert minden tóled telhetőt megtettél? }\end{array}$ & 1 & 2 & 3 & 4 & 5 \\
\hline $\begin{array}{l}\text { 9. Egy verseny után a szüleid megdicsérnek azért, } \\
\text { amilyen helyezést/eredményt elértél? }\end{array}$ & 1 & 2 & 3 & 4 & 5 \\
\hline $\begin{array}{l}\text { 10. Kimutatják a szüleid, hogy megértik a sportágaddal } \\
\text { kapcsolatos érzéseidet? }\end{array}$ & 1 & 2 & 3 & 4 & 5 \\
\hline $\begin{array}{l}\text { 11. A szüleid szoktak önkénteskedni a versenyeken, mint } \\
\text { rendezó, segítő vagy bármi más? }\end{array}$ & 1 & 2 & 3 & 4 & 5 \\
\hline $\begin{array}{l}\text { 12. A szüleid aktív szerepet vállalnak az egyesületed } \\
\text { múködésében? }\end{array}$ & 1 & 2 & 3 & 4 & 5 \\
\hline $\begin{array}{l}\text { 13. A szüleid bíztatnak arra, hogy elmond nekik bármilyen } \\
\text { problémádat és aggodalmadat? }\end{array}$ & 1 & 2 & 3 & 4 & 5 \\
\hline $\begin{array}{l}\text { 14. A szüleid nyomást gyakorolnak rád a sporttal } \\
\text { kapcsolatban? }\end{array}$ & 1 & 2 & 3 & 4 & 5 \\
\hline
\end{tabular}

\section{Kiértékelés:}

A kérdőívben nem található fordított item.

A skálaképzés a hozzájuk tartozó tételek összeadásával történik.

Direkt kontrolláló viselkedés alskála: 1., 2., 3. és 5. tétel

Dicséret és támogatás alskála: 4., 8., 9., 10. és 13. tétel

Szülői nyomásgyakorlás alskála: 6., 7. és 14. tétel

Aktív bevonódás alskála: 11. és 12. tétel 


\title{
Hungarian adaptation of Parental Involvement in Sport Questionnaire
}

\author{
KOVÁCS, KRISZTINA- F. FÖLDI, RITA - SMOHAI, MÁTÉ - \\ GÉCZI, GÁBOR - GYÖMBÉR, NOÉMI
}

Background and aims: The aim of the paper is to document the psychometric characteristics of the Hungarian version of Parental Involvement in Sport Questionnaire (PISQ-H) and test the reliability and validity of the instrument. Methods: In form of longitudinal study, we have tested the validity and reliability of the questionnaire with a convenient study sample consisted of 471 persons and aged between 13 and 21 years $(M=16.76, \mathrm{SD}=2.79$; boys: $40.3 \%$, girls: $54.2 \%$; missing data: 5.5\%). Perceived Autonomy Support Scale for Exercise Settings was applied for the validation. Results: Explorative factor analysis yielded four separated scales (Directive Behaviour, Praise and Understanding, Active Involvement and Parental Pressure). Internal consistency of the subscales (Cronbach's $a=0.64-0.85$ ) proved to be adequate (Cronbach- $a$ : 0.64-0.85). The analysis revealed significant $(p<0.001)$, positive and strong correlation coefficient for test-retest reliability (Praise and Understanding subscale: $r(67)=0.82$, Parental Pressure subscale: $r(67)=0.81$, Directive Behaviour subscale: $r(67)=0.93$, and Active Involvement subscale: $r(67)=0.94)$. Examination of constructum validity revealed small relationships $(r=0.30-0.56, p<0.001)$ - as it was found in the literature too - between the Perceived Autonomy Support Scale for Exercise Settings and the two subscales of PISQ-H $(r=0.30-0.56 ; p<0.001)$. Discussion: The Hungarian version of the Parental Involvement in Sport Questionnaire seems to be a valid and reliable questionnaire to measure.

Keywords: Parental Involvement in Sport Questionnaire, PISQ, sport, parental involvement, youth sport

A cikk a Creative Commons Attribution 4.0 International License (https:/ / creativecommons.org/ licenses/by/4.0/) feltételei szerint publikált Open Access közlemény, melynek szellemében a cikk bármilyen médiumban szabadon felhasználható, megosztható és újraközölhető, feltéve, hogy az eredeti szerző és a közlés helye, illetve a CC License linkje és az esetlegesen végrehajtott módosítások feltüntetésre kerülnek. (SID_1) 
